Research Paper

\title{
Nitric oxide-mediated inhibition of phenylephrine- induced contraction in response to hypothermia is partially modulated by endothelial Rho-kinase
}

\author{
Soo Hee Lee, ${ }^{1^{*}}$ Seong-Ho Ok, ${ }^{2^{*}}$ Raghavendra Baregundi Subbarao, ${ }^{1}$ Ji-Yoon Kim, ${ }^{3}$ Sung Il Bae, ${ }^{3}$ Yeran \\ Hwang, ${ }^{3}$ Seongyeong Tak, ${ }^{3}$ Ju-Tae Sohn ${ }^{1,4}{ }^{\boxplus}$ \\ 1. Department of Anesthesiology and Pain Medicine, Gyeongsang National University College of Medicine, Gyeongsang National University Hospital, 15 \\ Jinju-daero 816 beon-gil, Jinju-si, Gyeongsangnam-do, 52727, Republic of Korea. \\ 2. Department of Anesthesiology and Pain Medicine, Gyeongsang National University Changwon Hospital, Changwon, 51427, Republic of Korea. \\ 3. Department of Anesthesiology and Pain Medicine, Gyeongsang National University Hospital, 15 Jinju-daero 816 beon-gil, Jinju-si, Gyeongsangnam-do, \\ 52727, Republic of Korea. \\ 4. Institute of Health Sciences, Gyeongsang National University, Jinju-si, 52727, Republic of Korea. \\ *These authors contributed equally to the work
}

$\square$ Corresponding author: Ju-Tae Sohn; Department of Anesthesiology and Pain Medicine, Gyeongsang National University Hospital, 79 Gangnam-ro, Jinju-si, 52727, Republic of Korea; E-mail: jtsohn@gnu.ac.kr., Tel.: +82-55-750-8586, Fax: +82-55-750-8142.

(C) The author(s). This is an open access article distributed under the terms of the Creative Commons Attribution License (https://creativecommons.org/licenses/by/4.0/). See http://ivyspring.com/terms for full terms and conditions.

Received: 2019.08.06; Accepted: 2019.11.07; Published: 2020.01.01

\begin{abstract}
This study examined the possible upstream cellular signaling pathway associated with nitric oxide (NO)-mediated inhibition of phenylephrine-induced contraction in isolated rat aortae in response to mild hypothermia, with a particular focus on endothelial Rho-kinase. We examined the effects of mild hypothermia $\left(33^{\circ} \mathrm{C}\right)$, wortmannin, $\mathrm{N}^{\omega}$-nitro-L-arginine methyl ester (L-NAME), Y-27632, $1 \mathrm{H}-[1,2,4]$ oxadiazolo[4,3-a]quinoxalin-1-one (ODQ) and methylene blue, alone and combined, on phenylephrine-induced contraction in isolated rat aortae. Finally, we examined the effects of mild hypothermia, wortmannin, Y-27632 and L-NAME, alone and combined, on endothelial nitric oxide synthase (eNOS) and endothelial Rho-kinase membrane translocation induced by phenylephrine. Mild hypothermia attenuated phenylephrine-induced contraction only in endothelium-intact aortae. L-NAME, wortmannin, ODQ and methylene blue increased phenylephrine-induced contraction of endothelium-intact aortae pretreated at $33^{\circ} \mathrm{C}$. Wortmannin did not significantly alter the L-NAME-induced enhancement of phenylephrine-induced maximal contraction of endotheliumintact aortae pretreated at $33^{\circ} \mathrm{C}$. Wortmannin abolished the ability of Y-27632 to magnify the hypothermic inhibition of maximal phenylephrine-induced contraction. Wortmannin and L-NAME inhibited the enhancing effect of mild hypothermia on phenylephrine-induced eNOS phosphorylation. Y-27632 and L-NAME attenuated the enhancing effect of hypothermia on phenylephrine-induced endothelial Rho-kinase membrane translocation. The results suggest that hypothermia-induced, NO-dependent inhibition of phenylephrine-induced contraction is mediated by phosphoinositide 3-kinase and inhibited by endothelial Rho-kinase activation.
\end{abstract}

Key words: hypothermia; nitric oxide; phenylephrine; endothelial Rho-kinase; contraction; aorta; phosphoinositide 3-kinase

\section{Introduction}

Hypothermia may exert a neuroprotective effect in traumatic brain injury [1,2]. The alpha-adrenoceptor agonist phenylephrine can be used to improve cerebral perfusion pressure that has been compromised by hypothermia-induced hypotension, which is regarded as a side effect of hypothermia [1,2]. Mild hypothermia $\left(34^{\circ} \mathrm{C}\right)$ attenuates phenylephrine-induced contraction by increasing nitric oxide (NO) production [3]. In addition, norepinephrine-induced contraction is 
attenuated by hypothermia in isolated rat aortae, and this attenuation is inhibited by removal of the endothelium [4]. Moderate hypothermia $\left(25\right.$ to $31^{\circ} \mathrm{C}$ ) reduces phenylephrine-induced contraction via the NO-cyclic guanosine monophosphate (cGMP) pathway [5]. Endothelial phosphoinositide 3-kinase (PI3K)-induced NO production modulates phenylephrine-induced contraction in endotheliumintact aortae, and this effect seems to be inhibited by endothelial Rho-kinase [6,7]. In addition, endothelium-dependent NO-induced relaxation is mediated partially by inhibition of the RhoA and Rhokinase pathways in endothelium-intact arteries [8]. The Rho-kinase inhibitor Y-27632 inhibits phenylephrine-induced contraction only in endotheliumintact rat aortae, whereas pretreatment with $\mathrm{NO}$ synthase inhibitor $\mathrm{N}^{\omega}$-nitro-L-arginine methyl ester (L-NAME) attenuates Y-27632-mediated inhibition of phenylephrine-induced contraction [9]. Furthermore, NO-mediated vasodilation of cavernosal arterioles can overcome Rho-kinase-mediated vasoconstriction to produce penile erection [10]. The cholesterollowering drugs known as statins inhibit 3-hydroxy-3methylglutaryl-coenzyme A, thereby inhibiting the synthesis of isoprenoids (geranyl-geranyl pyrophosphate) and cholesterol, leading to inhibition of Rho-kinase and increased NO production [11]. Combined treatment with the Rho-kinase inhibitor fasudil and statins prevents cerebral spasm after subarachnoid hemorrhage [12]. However, exposure to cold temperatures causes vessels to constrict via a mechanism involving reactive oxygen speciesinduced activation of Rho-kinase, alpha-2 adrenoceptor translocation and decreased $\mathrm{NO}$ production [13]. Cold-induced activation of Rhokinase also causes vasoconstriction via the inhibition of myosin light chain phosphatase (MLCP) and decreased NO production [13]. Taken together, these previous reports suggest that hypothermia-induced Rho-kinase activation inhibits NO-dependent vasodilation [8-13]. Therefore, we tested the hypothesis that endothelial Rho-kinase inhibits hypothermiainduced NO-mediated attenuation of phenylephrineinduced contraction [6-13]. The goal of this study was to examine the possible upstream cellular signaling pathway associated with hypothermia-induced NOmediated attenuation of phenylephrine-induced contraction in the isolated rat aorta, with a particular focus on endothelial Rho-kinase.

\section{Materials and Methods}

The experimental protocol and methods were approved by the Institutional Animal Care and Use Committee of Gyeongsang National University. All the experimental protocols complied with the regulations in the Guideline for the Care and Use of Laboratory Animal prepared by Gyeongsang National University.

\section{Preparation of rat thoracic aortae and subsequent isometric tension measurement}

Isolated rat thoracic aortae were prepared for isometric tension measurement as described previously by our laboratory $[14,15]$. Male SpragueDawley rats (250-300 grams) were euthanized with $100 \%$ carbon dioxide supplied via a small hole in the cage. After the descending thoracic aorta of each rat was removed from the thorax, the perivascular connective tissue and fat were removed under a microscope. As there are regional differences in vasoreactivity to acetylcholine in endothelium-intact rat aortae, the descending thoracic aorta was used throughout the current study [16]. Each aorta was cut into small aortic rings measuring 2.5 to $3 \mathrm{~mm}$ in length. These rings were suspended in a Grass isometric force transducer (FT-03, Grass Instrument Co., Quincy, MA, USA) with a resting tension of 3.0 in a $10-\mathrm{mL}$ organ bath full of $37^{\circ} \mathrm{C}$ Krebs solution. The resting tension of $3.0 \mathrm{~g}$ was maintained for $120 \mathrm{~min}$ to reach equilibrium. The Krebs solution was exchanged for fresh Krebs solution every $30 \mathrm{~min}$. The endothelium of some isolated rat thoracic aortae was removed to produce endothelium-denuded rat thoracic aortae. To remove the endothelium from isolated rat thoracic aortae, two 25-gauge needles were inserted into the lumen of the aorta, and the aorta was then rotated around the two needles. To confirm endothelial denudation, we induced contraction by adding phenylephrine $\left(10^{-8} \mathrm{M}\right)$ to the organ bath. After phenylephrine produced a sustained and stable contraction, acetylcholine $\left(10^{-5}\right.$ M) was added to the organ bath to assess endothelium-dependent relaxation, and less than 15\% acetylcholine-induced relaxation was considered to indicate endothelium denudement. To confirm endothelial integrity, we added phenylephrine $\left(10^{-7}\right.$ M) to the organ bath. After phenylephrine $\left(10^{-7} \mathrm{M}\right)$ produced a stable and sustained contraction in the endothelium-intact rat aorta, acetylcholine $\left(10^{-5} \mathrm{M}\right)$ was added to the organ bath to assess endothelial integrity. In this experiment, more than $80 \%$ acetylcholine-induced relaxation was considered to indicate that the endothelium was intact. Isolated rat aortae showing acetylcholine-induced relaxation from phenylephrine-induced contraction were washed with fresh Krebs solution to restore baseline resting tension. Then, contraction was elicited with isotonic $60 \mathrm{mM} \mathrm{KCl}$ as a reference value to compare the magnitude of contraction induced by cumulative addition of phenylephrine in endothelium-intact and 
endothelium-denuded rat aortae. After contraction was elicited with isotonic $60 \mathrm{mM} \mathrm{KCl}$, the isolated rat thoracic aortae were washed with fresh Krebs solution to restore baseline resting tension prior to the following experimental protocols.

\section{Experimental protocols}

First, we examined the effect of mild hypothermia $\left(33^{\circ} \mathrm{C}\right)$ on phenylephrine-induced contraction in endothelium-intact and endotheliumdenuded rat aortae. After the isolated endotheliumintact and endothelium-denuded rat aortae were pretreated at 38 or $33^{\circ} \mathrm{C}$ for $30 \mathrm{~min}$, phenylephrine $\left(10^{-9}\right.$ to $\left.10^{-5} \mathrm{M}\right)$ was added cumulatively to the organ bath to produce phenylephrine concentrationresponse curves. As mild hypothermia $\left(32\right.$ to $\left.35^{\circ} \mathrm{C}\right)$ is used to reduce neurologic deficits in patients with ruptured intracranial aneurysms, we chose a temperature of $33^{\circ} \mathrm{C}$ to for the mild hypothermia condition in our study [17].

Second, we examined the effects of the PI3K inhibitor wortmannin $\left(10^{-7} \mathrm{M}\right)$ and the NO synthase inhibitor L-NAME $\left(10^{-4} \mathrm{M}\right)$ on phenylephrine-induced contraction in endothelium-intact rat aortae pretreated at 33 or $38^{\circ} \mathrm{C}$. After isolated endotheliumintact rat aortae were treated at 38 or $33^{\circ} \mathrm{C}$ for $30 \mathrm{~min}$ in the presence or absence of L-NAME or wortmannin, phenylephrine $\left(10^{-9}\right.$ to $\left.10^{-5} \mathrm{M}\right)$ was added cumulatively to the organ bath to produce phenylephrine concentration-response curves.

Third, we examined the effects of wortmannin $\left(10^{-7} \mathrm{M}\right)$ alone and the combination of L-NAME $\left(10^{-4}\right.$ $\mathrm{M})$ and wortmannin $\left(10^{-7} \mathrm{M}\right)$ on the maximal contraction induced by phenylephrine $\left(10^{-5} \mathrm{M}\right)$ in endothelium-intact rat aortae pretreated at 38 or $33^{\circ} \mathrm{C}$ for $30 \mathrm{~min}$. After phenylephrine $\left(10^{-5} \mathrm{M}\right)$ produced maximal sustained and stable contraction in endothelium-intact rat aortae pretreated at 38 or $33^{\circ} \mathrm{C}$ for $30 \mathrm{~min}$, wortmannin $\left(10^{-7} \mathrm{M}\right)$ alone or L-NAME $\left(10^{-4} \mathrm{M}\right)$ followed by wortmannin $\left(10^{-7} \mathrm{M}\right)$ was added to the organ bath to investigate their effect on the maximal contraction induced by phenylephrine $\left(10^{-5}\right.$ $\mathrm{M})$ at 38 or $33^{\circ} \mathrm{C}$. After the addition of L-NAME $\left(10^{-4}\right.$ $\mathrm{M})$ produced a sustained and stable effect on maximal phenylephrine $\left(10^{-5} \mathrm{M}\right)$-induced contraction, wortmannin $\left(10^{-7} \mathrm{M}\right)$ was added to the organ bath.

Fourth, we examined the effect of either combined Y-27632 $\left(10^{-6} \mathrm{M}\right)$, wortmannin $\left(10^{-7} \mathrm{M}\right)$ and L-NAME $\left(10^{-4} \mathrm{M}\right)$ or combined L-NAME $\left(10^{-4} \mathrm{M}\right)$ and Y-27632 $\left(10^{-6} \mathrm{M}\right)$ on the maximal phenylephrine $\left(10^{-5}\right.$ $\mathrm{M})$-induced contraction in endothelium-intact rat aortae pretreated at 38 or $33^{\circ} \mathrm{C}$ for $30 \mathrm{~min}$. After phenylephrine $\left(10^{-5} \mathrm{M}\right)$ produced maximal sustained contraction in endothelium-intact rat aortae pretreated at 38 or $33^{\circ} \mathrm{C}$ for $30 \mathrm{~min}$, either Y-27632 $\left(10^{-6} \mathrm{M}\right)$, wortmannin $\left(10^{-7} \mathrm{M}\right)$ and L-NAME $\left(10^{-4} \mathrm{M}\right)$ or L-NAME $\left(10^{-4} \mathrm{M}\right)$ and Y-27632 $\left(10^{-6} \mathrm{M}\right)$ were added sequentially to the organ bath to investigate the cumulative effect of either Y-27632, wortmannin and L-NAME or L-NAME and Y-27632 on the maximal phenylephrine $\left(10^{-5} \mathrm{M}\right)$-induced contraction at 38 or $33^{\circ} \mathrm{C}$. After the previously added inhibitor produced a sustained and stable effect on maximal phenylephrine $\left(10^{-5} \mathrm{M}\right)$-induced contraction, different inhibitors were added to the organ bath.

Finally, we examined the effect of the guanylate cyclase (GC) inhibitor methylene blue $\left(3 \times 10^{-6} \mathrm{M}\right)$ and the NO-sensitive GC inhibitor $1 \mathrm{H}-[1,2,4]$ oxadiazolo [4,3-a]quinoxalin-1-one (ODQ, $10^{-5} \mathrm{M}$ ) on phenylephrine-induced contraction in endothelium-intact rat aortae pretreated at $33^{\circ} \mathrm{C}$ for $30 \mathrm{~min}$. After isolated endothelium-intact rat aortae were treated at $33^{\circ} \mathrm{C}$ for $30 \mathrm{~min}$ in the presence or absence of methylene blue or ODQ, phenylephrine $\left(10^{-9}\right.$ to $\left.10^{-5} \mathrm{M}\right)$ was cumulatively added to the organ bath to produce phenylephrine concentration-response curves. All the concentrations of various inhibitors, including LNAME, wortmannin, Y-27632, ODQ and methylene blue, were selected on the basis of previous reports $[18,19]$.

\section{Cell culture}

Human umbilical vein endothelial cells (HUVECs, EA.hy926 cells, American Type Culture Collection, Manassas, VA, USA) were cultured in Dulbecco's modified Eagle's medium (HyClone, GE Healthcare, UT, USA) supplemented with 10\% heat-inactivated fetal bovine serum (Gibco, Life Technologies, NY, USA), 2 mM l-glutamine, 100 U/ml penicillin, and $100 \mu \mathrm{g} / \mathrm{ml}$ streptomycin as previously described [20,21]. Cells were plated in a 100-mm culture dish and incubated at $37^{\circ} \mathrm{C}$ in a humidified atmosphere containing $5 \% \mathrm{CO}_{2}$. The medium was changed every other day until the cells reached confluence. Upon reaching confluence, the cells were dissociated with $0.025 \%$ trypsin-ethylenediaminetetraacetic acid solution and split at a 1:4 ratio. For our experiments, cells between passages 2 and 5 were seeded in dishes ( $10^{5}$ cells $/ 100-\mathrm{mm}$ dish) and cultured until they reached $70 \%$ confluence, followed by serum starvation overnight prior to drug treatment.

\section{Western blot analysis}

Western blot analysis was carried out as described previously $[18,19,21]$. Cytosolic and membrane fractions were isolated from cells using a Mem-PER ${ }^{\circledR}$ eukaryotic membrane protein extraction reagent kit (ThermoFisher Scientific, MA, USA) according to the manufacturer's instructions. Cells were lysed in the appropriate protein extraction 
solutions to obtain separate cytosolic and membrane fractions by centrifugation at $16,000 \times \mathrm{g}$ for $15 \mathrm{~min}$ at $4^{\circ} \mathrm{C}$. After extraction, the protein concentrations were determined using the Bradford method. The protein samples to be loaded in the gel were prepared by mixing equal volumes of protein lysates with $2 \times$ sodium dodecyl sulfate sample buffer $(0.1 \mathrm{M}$ Tris- $\mathrm{HCl}, 20 \%$ glycerol, $4 \%$ sodium dodecyl sulfate, and $0.01 \%$ bromophenol blue). A total of $30 \mu \mathrm{g}$ protein per sample was separated by $7 \%$ or $10 \%$ sodium dodecyl sulfate-polyacrylamide gel electrophoresis for $90 \mathrm{~min}$ at $110 \mathrm{~V}$. The separated proteins were electrophoretically transferred to polyvinylidene difluoride membranes for $1 \mathrm{~h}$ at $190 \mathrm{~mA}$. Then, the membranes were blocked in Tris-buffered saline containing TWEEN 20 (TBST) with $5 \% \mathrm{w} / \mathrm{v}$ nonfat dried milk for $2 \mathrm{~h}$ at room temperature and incubated overnight at $4^{\circ} \mathrm{C}$ with specific primary antibodies (anti-endothelial nitric oxide synthase [eNOS] and anti-phospho-eNOS) diluted 1:1,000 in TBST containing $5 \% \mathrm{w} / \mathrm{v}$ skim milk powder or $5 \%$ BSA. After washing the membranes in TBST, bound antibodies were incubated with horseradish peroxidase-conjugated anti-rabbit or anti-mouse IgG diluted 1:5,000 in TBST containing 5\% w/v skim milk for $1 \mathrm{~h}$ at room temperature. The membranes were washed in TBST, and the immunoreactive bands were detected by chemiluminescence (SuperSignal ${ }^{\circledR}$ West Pico Chemiluminescent Substrate; Thermo Scientific, Rockford, IL, USA) using X-ray film (SuperRX-N Fuji Medical X-ray Film, Japan).

\section{Materials}

All the chemicals were of the highest purity and obtained from commercial sources. Phenylephrine, L-NAME, wortmannin, ODQ and methylene blue were purchased from Sigma-Aldrich (St. Louis, MO, USA). Y-27632 was obtained from Calbiochem (La Jolla, CA, USA). Anti-eNOS and anti-phospho-eNOS $\left(\right.$ Ser $\left.{ }^{1177}\right)$ antibodies were obtained from Cell Signaling Technology (Beverly, MA, USA). PRO-PREP protein extraction solution and electrochemiluminescence Western blotting detection reagents were supplied by iNtRON Biotechnology (Houston, TX, USA). All chemical concentrations are expressed as the final molar concentration in the organ bath. The wortmannin and ODQ were dissolved in dimethyl sulfoxide (final organ bath concentration: $0.01 \%$ ).

\section{Data analysis}

The data are shown as the mean \pm SD and are expressed as the percentage of maximal contraction induced by isotonic $60 \mathrm{mM} \mathrm{KCl}$ or phenylephrine $\left(10^{-5}\right.$ $\mathrm{M})$. The logarithm $\left(\log \mathrm{ED}_{50}\right)$ of the phenylephrine concentration that induced half of the maximal concentration induced by isotonic $60 \mathrm{mM} \mathrm{KCl}$ was calculated using nonlinear regression analysis by fitting the phenylephrine concentration-response curve to a sigmoidal dose-response curve generated by Prism 5.0 (GraphPad Software, San Diego, USA). The effects of mild hypothermia and various inhibitors, alone or combined, on the $\log \mathrm{ED}_{50}$ and maximal phenylephrine-induced contraction were analyzed using one-way analysis of variance (ANOVA) followed by Bonferroni's post hoc test or an unpaired Student's t-test. The effect of the combined addition of various inhibitors on the phenylephrine-induced maximal contraction at 33 and $38^{\circ} \mathrm{C}$ was analyzed by repeated-measures ANOVA followed by Bonferroni's post hoc test. The effect of mild hypothermia on the inhibitor-induced change in phenylephrine-induced maximal contraction was analyzed using two-way repeated-measures ANOVA followed by Bonferroni's post hoc test. The effects of mild hypothermia and various inhibitors, alone or combined, on phenylephrine-induced eNOS phosphorylation and endothelial Rho-kinase membrane translocation were analyzed using one-way ANOVA followed by Bonferroni's post hoc test. A $P$ value less than 0.05 was considered statistically significant.

\section{Results}

Mild hypothermia $\left(33^{\circ} \mathrm{C}\right)$ attenuated phenylephrine-induced maximal contraction in endothelium-intact rat aortae (Fig. 1A; $P<0.001$ versus $38^{\circ} \mathrm{C}$; Table 1) but did not significantly alter phenylephrine-induced contraction in endotheliumdenuded rat aortae (Fig. 1B; Table 1). The PI3K inhibitor wortmannin $\left(10^{-7} \mathrm{M}\right)$ enhanced phenylephrine-induced maximal contraction in endothelium-intact rat aortae pretreated at $33^{\circ} \mathrm{C}$ (Fig. 2A; $P$ $<0.01$ versus $33^{\circ} \mathrm{C}$ pretreatment only; Table 2$)$. In addition, wortmannin caused a leftward shift in the phenylephrine concentration-response curve (Fig. 2A, $\log \mathrm{ED}_{50}: P<0.05$ versus $38^{\circ} \mathrm{C}$ alone; Table 2) in endothelium-intact rat aortae pretreated at $38^{\circ} \mathrm{C}$ but it did not significantly alter phenylephrine-induced maximal contraction (Fig. 2A; Table 2). Pretreatment with the NO synthase inhibitor L-NAME $\left(10^{-4} \mathrm{M}\right)$ enhanced phenylephrine-induced contraction in endothelium-intact rat aortae pretreated at $38^{\circ} \mathrm{C}$ or $33^{\circ} \mathrm{C}$ (Fig. 2B; maximal contraction: $P<0.001$ versus $33^{\circ} \mathrm{C}$ pretreatment only; log $\mathrm{ED}_{50}: P<0.001$ versus $38^{\circ} \mathrm{C}$ or $33^{\circ} \mathrm{C}$ pretreatment only; Table 2). However, when endothelium-intact rat aortae were treated with L-NAME $\left(10^{-4} \mathrm{M}\right)$, compared with exposure to $38^{\circ} \mathrm{C}$, mild hypothermia $\left(33^{\circ} \mathrm{C}\right)$ did not significantly alter phenylephrine-induced contraction (Fig. 2B; Table 2). 
Table 1. Effect of mild hypothermia on phenylephrine-induced contraction in isolated rat aortae

\begin{tabular}{lllllll}
\hline & \multicolumn{2}{l}{ Endothelium-intact aortae } & \multicolumn{3}{l}{ Endothelium-denuded aortae } \\
\cline { 2 - 6 } & $\mathrm{N}$ & LogED50 & Max contraction $(\%)$ & $\mathrm{N}$ & LogED50 & Max contraction (\%) \\
\hline $38^{\circ} \mathrm{C}$ & 6 & $6.92 \pm 0.23$ & $75 \pm 12$ & 7 & $7.83 \pm 0.21$ & $119 \pm 10$ \\
$33^{\circ} \mathrm{C}$ & 6 & $6.90 \pm 0.13$ & $44 \pm 7^{*}$ & 8 & $7.86 \pm 0.21$ & $110 \pm 9$ \\
\hline
\end{tabular}

Data are shown as the mean \pm SD. N indicates the number of rats for the endothelium-intact condition or the number of isolated aortae for the endothelium-denuded condition. $\log \mathrm{ED}_{50}$ : Logarithm of phenylephrine concentration to produce half of the maximal contraction induced by isotonic $60 \mathrm{mM} \mathrm{KCl}$. Max contraction: Maximal contraction induced by phenylephrine, which is expressed as the percentage of isotonic $60 \mathrm{mM} \mathrm{KCl}$-induced maximal contraction. ${ }^{*} P<0.001$ versus $38^{\circ} \mathrm{C}$.

Table 2. Effect of L-NAME and wortmannin on phenylephrine-induced contraction in isolated endothelium-intact rat aortae pretreated with 38 or $33^{\circ} \mathrm{C}$

\begin{tabular}{|c|c|c|c|c|c|c|}
\hline & \multicolumn{3}{|c|}{$38^{\circ} \mathrm{C}$} & \multicolumn{3}{|c|}{$33^{\circ} \mathrm{C}$} \\
\hline & $\mathrm{N}$ & $\operatorname{LogED}_{50}$ & Max contraction (\%) & $\mathrm{N}$ & $\operatorname{LogED}_{50}$ & Max contraction (\%) \\
\hline Control & 6 & $6.94 \pm 0.16$ & $80 \pm 11 \ddagger$ & 6 & $6.89 \pm 0.13$ & $53 \pm 8$ \\
\hline Wortmannin (10-7 M) & 6 & $7.21 \pm 0.11^{*}$ & $84 \pm 14 \ddagger$ & 6 & $6.99 \pm 0.20$ & $76 \pm 11 \dagger$ \\
\hline Control & 5 & $7.04 \pm 0.12$ & $94 \pm 11 \S$ & 5 & $7.00 \pm 0.14$ & $70 \pm 14$ \\
\hline L-NAME (10-4 M) & 6 & $7.58 \pm 0.14 \#$ & $113 \pm 11^{* *}$ & 6 & $7.55 \pm 0.23 \#$ & $110 \pm 6 \#$ \\
\hline
\end{tabular}

Data are shown as the mean \pm SD. N indicates the number of rats. Log $\mathrm{ED}_{50}$ : Logarithm of phenylephrine concentration to produce half of the maximal contraction induced by isotonic $60 \mathrm{mM} \mathrm{KCl}$. Max contraction: Maximal contraction induced by phenylephrine, which is expressed as the percentage of isotonic $60 \mathrm{mM} \mathrm{KCl-induced} \mathrm{maximal}$ contraction. ${ }^{*} P<0.05, \uparrow P<0.01$ and $\# P<0.001$ versus control. $\S P<0.05, \ddagger P<0.01$ and ${ }^{* *} P<0.001$ versus $33^{\circ} \mathrm{C}$ pretreatment only.
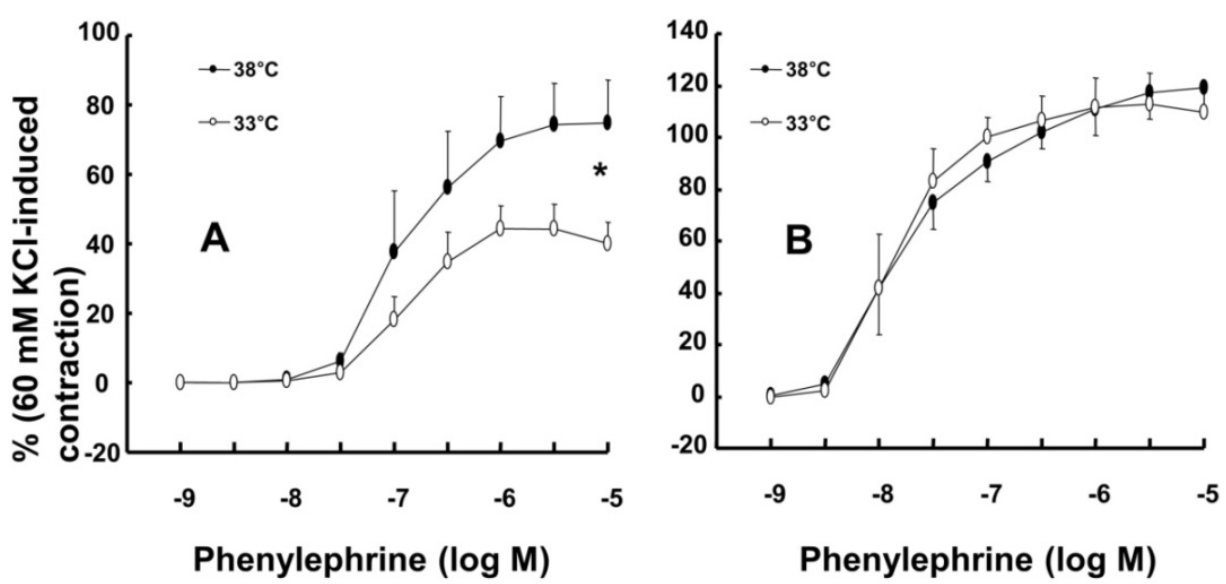

Figure 1. Effect of mild hypothermia $\left(33^{\circ} \mathrm{C}\right)$ on phenylephrine-induced contraction in isolated endothelium-intact $(A, N=6)$ and endothelium-denuded $\left(B, 38^{\circ} \mathrm{C}: \mathrm{N}\right.$ $=7 ; 33^{\circ} \mathrm{C}: \mathrm{N}=8$ ) rat aortae. The data represent the mean $\pm \mathrm{SD}$ and are expressed as a percentage of the maximal contraction induced by isotonic $60 \mathrm{mM} \mathrm{KCl}$. $\mathrm{N}$ indicates the number of rats $(\mathrm{A})$ or the number of isolated descending thoracic aortic rings $(\mathrm{B})$. Maximal contraction: $* P<0.001$ versus $38^{\circ} \mathrm{C}$.
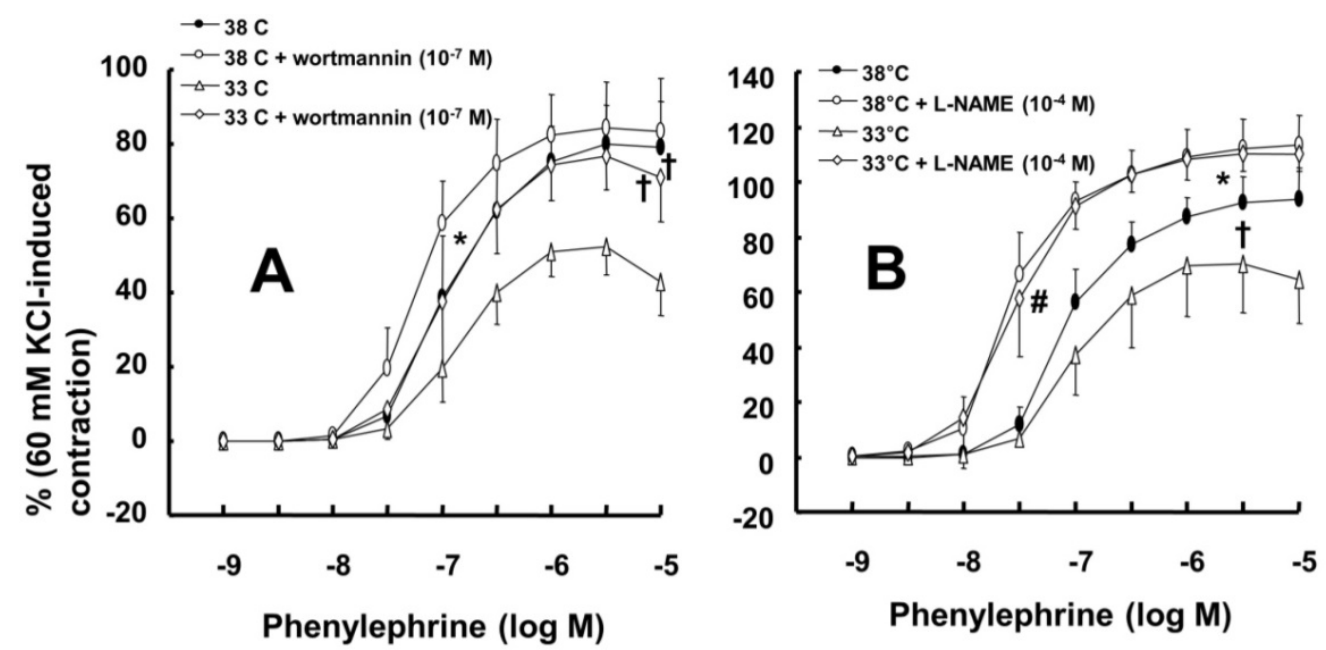

Figure 2. A: Effects of mild hypothermia $\left(33^{\circ} \mathrm{C}\right)$ and wortmannin, alone and combined, on phenylephrine-induced contraction in isolated endothelium-intact aortae. The data $(\mathrm{N}=6)$ represent the mean $\pm \mathrm{SD}$ and are expressed as a percentage of the maximal contraction induced by isotonic $60 \mathrm{mM} \mathrm{KCl}$. $\mathrm{N}$ indicates the number of rats from which descending thoracic aortic rings were obtained. Log $\mathrm{ED} \mathrm{D}_{50}$ : $* \mathrm{P}<0.05$ versus $38^{\circ} \mathrm{C}$ pretreatment only. Maximal contraction: $\nmid \mathrm{P}<0.01$ versus $33^{\circ} \mathrm{C}$ pretreatment only. B: Effect of mild hypothermia and $\mathrm{N}^{\omega}$-nitro-l-arginine methyl ester (L-NAME), alone and combined, on phenylephrine-induced contraction in isolated endothelium-intact aortae. Data $\left(38\right.$ or $33^{\circ} \mathrm{C}: \mathrm{N}=5 ; 38$ or $33^{\circ} \mathrm{C}+\mathrm{L}-\mathrm{NAME}: \mathrm{N}=6$ ) are shown as the mean $\pm \mathrm{SD}$ and expressed as the percentage of the maximal contraction induced by isotonic $60 \mathrm{mM} \mathrm{KCl}$. N indicates the number of rats from which descending thoracic aortic rings were obtained. Maximal contraction: $* P<0.001$ and $\dagger P<0.05$ versus $33^{\circ} \mathrm{C}$ pretreatment only. $\log E D_{50}: \# P<0.001$ versus $38^{\circ} \mathrm{C}$ or $33^{\circ} \mathrm{C}$ pretreatment only. 

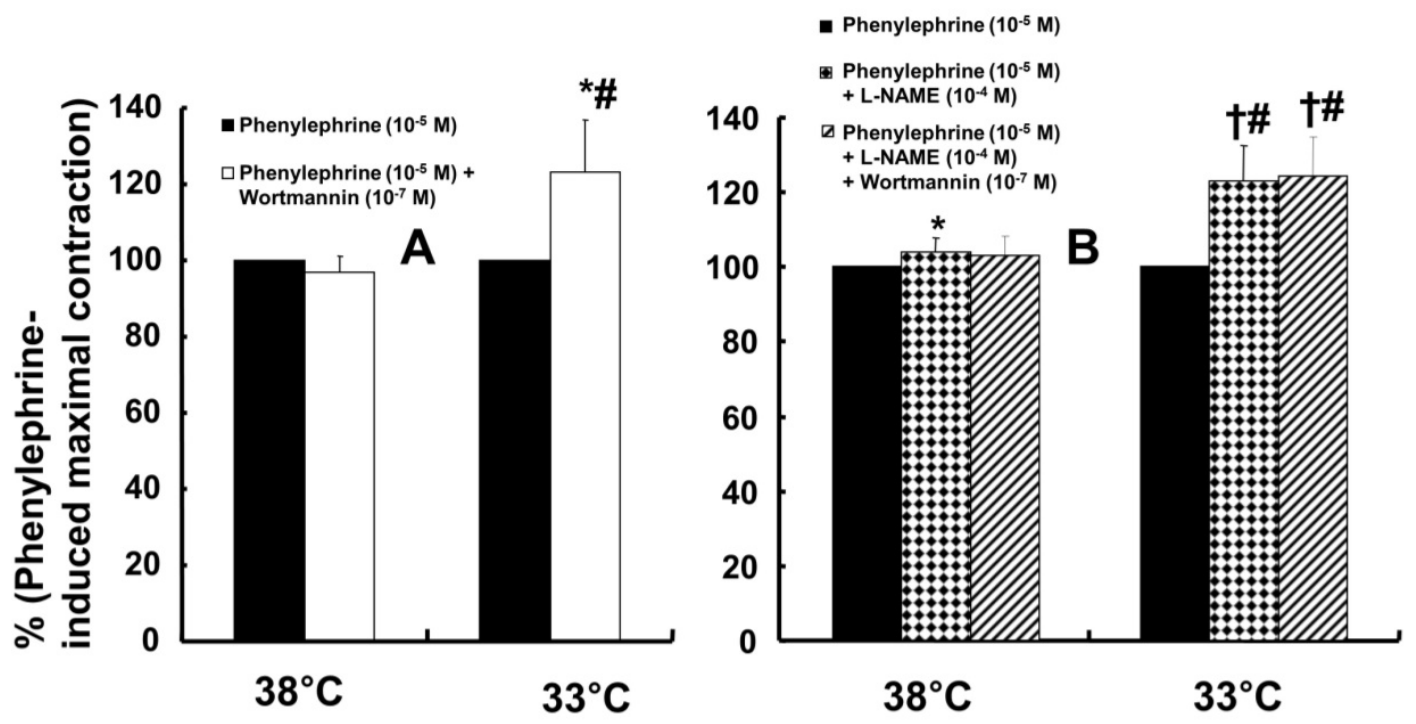

Figure 3. Effects of either wortmannin $\left(\mathbf{A} ; 38^{\circ} \mathrm{C}: \mathrm{N}=6 ; 33^{\circ} \mathrm{C}: \mathrm{N}=7\right)$ or the combination $\left(\mathbf{B} ; 38^{\circ} \mathrm{C}: \mathrm{N}=8 ; 33^{\circ} \mathrm{C}: \mathrm{N}=10\right)$ of $N^{\omega}$-nitro-L-arginine-methyl ester (L-NAME, 10-4 M) and wortmannin on phenylephrine-induced maximal contraction in isolated endothelium-intact rat aortae pretreated at $33^{\circ} \mathrm{C}$ or $38^{\circ} \mathrm{C}$. The data are shown as the mean $\pm S D$ and the percentage of maximal contraction induced by phenylephrine $\left(10^{-5} \mathrm{M}\right)$. $\mathrm{N}$ indicates the number of isolated rat aortae. $* P<0.01$ and $\dagger P<0.001$ versus phenylephrine alone. $\# P<0.001$ versus $38^{\circ} \mathrm{C}$.

Wortmannin $\left(10^{-7} \mathrm{M}\right)$ did not significantly alter phenylephrine $\left(10^{-5} \mathrm{M}\right)$-induced maximal contraction in endothelium-intact rat aortae pretreated at $38^{\circ} \mathrm{C}$ (Fig. 3A), but it enhanced phenylephrine $\left(10^{-5}\right.$ $\mathrm{M})$-induced maximal contraction in endotheliumintact rat aortae pretreated at $33^{\circ} \mathrm{C}$ (Fig. 3A; $P<0.001$ versus phenylephrine alone at $33^{\circ} \mathrm{C}$ ). Posttreatment with L-NAME slightly increased phenylephrineinduced maximal contraction in endothelium-intact rat aortae pretreated at $38^{\circ} \mathrm{C}$ (Fig. 3B; $P<0.001$ versus phenylephrine alone at $\left.38^{\circ} \mathrm{C}\right)$. Subsequent posttreatment with wortmannin $\left(10^{-7} \mathrm{M}\right)$ did not significantly alter phenylephrine-induced maximal contraction compared with phenylephrine alone or phenylephrine plus L-NAME. In contrast, posttreatment with L-NAME $\left(10^{-4} \mathrm{M}\right)$ or L-NAME $\left(10^{-4} \mathrm{M}\right)$ plus wortmannin $\left(10^{-7} \mathrm{M}\right)$ remarkably increased phenylephrine-induced maximal contraction in endothelium-intact rat aortae at $33^{\circ} \mathrm{C}$ (Fig. 3B; $P<$ 0.001 versus phenylephrine alone at $33^{\circ} \mathrm{C}$ ); the subsequent addition of wortmannin did not significantly alter the increased phenylephrineinduced maximal contraction induced by L-NAME in endothelium-intact rat aortae at $33^{\circ} \mathrm{C}$ (Fig. 3B). The increase in phenylephrine-induced maximal contraction induced by L-NAME alone or L-NAME plus wortmannin was more pronounced under hypothermic conditions $\left(33^{\circ} \mathrm{C}\right)$ than at $38^{\circ} \mathrm{C}$ (Fig. 3B; $P<$ 0.001). Posttreatment with Y-27632 (10-6 M) decreased phenylephrine-induced maximal contraction in endothelium-intact rat aortae (Fig. 4A; $P<0.001$ versus phenylephrine alone), and subsequent posttreatment with wortmannin $\left(10^{-7} \mathrm{M}\right)$ increased phenylephrine-induced maximal contraction in endothelium-intact rat aortae treated at $38^{\circ} \mathrm{C}$ or $33^{\circ} \mathrm{C}$ (Fig. 4A; $P<0.001$ versus $\mathrm{Y}-27632$ ). At both $38^{\circ} \mathrm{C}$ and $33^{\circ} \mathrm{C}$ subsequent cumulative posttreatment with L-NAME further increased phenylephrine $\left(10^{-5}\right.$ $\mathrm{M})$-induced maximal contraction in endotheliumintact rat aortae that had been previously treated with Y-27632 and wortmannin (Fig. 4A; $P<0.001$ versus Y-27632 and wortmannin). Hypothermia $\left(33^{\circ} \mathrm{C}\right)$ enhanced Y-27632-induced inhibition of phenylephrine $\left(10^{-5} \mathrm{M}\right)$-induced maximal contraction in the endothelium-intact rat aortae compared with treatment at $38^{\circ} \mathrm{C}$ (Fig. 4A; $P<0.001$ ). However, after wortmannin-mediated reversal of the effect of Y-27632, there was no longer a significant difference in maximal phenylephrine-induced contraction between aortae treated at $33^{\circ} \mathrm{C}$ and those treated at $38^{\circ} \mathrm{C}$ (Fig. 4A). Furthermore, hypothermia $\left(33^{\circ} \mathrm{C}\right)$ augmented the ability of L-NAME to increase phenylephrine-induced maximal contraction in endothelium-intact rat aortae pretreated with both Y-27632 and wortmannin (Fig. 4A; $P<0.001$ ). Posttreatment with L-NAME $\left(10^{-4} \mathrm{M}\right)$ increased phenylephrine-induced maximal contraction in endothelium-intact rat aortae pretreated at $38^{\circ} \mathrm{C}$ or $33^{\circ} \mathrm{C}$ (Fig. 4B; $P<0.001$ ), and subsequent posttreatment with Y-27632 decreased phenylephrineinduced contraction (Fig. 4B; $P<0.001$ versus L-NAME only). Compared with treatment at $38^{\circ} \mathrm{C}$, hypothermia $\left(33^{\circ} \mathrm{C}\right)$ augmented the ability of L-NAME to increase phenylephrine-induced maximal contraction in endothelium-intact rat aortae (Fig. 4B; $P$ $<0.001$ ), but when Y-27632 was then added, there was 
no longer a significant difference in phenylephrine $\left(10^{-5} \mathrm{M}\right)$-induced maximal contraction in endothelium-intact rat aortae treated at $33^{\circ} \mathrm{C}$ or $38^{\circ} \mathrm{C}$ (Fig. $4 \mathrm{~B})$. The GC inhibitor methylene blue $\left(3 \times 10^{-6} \mathrm{M}\right)$ increased phenylephrine-induced contraction in endothelium-intact rat aortae pretreated at $33^{\circ} \mathrm{C}$ (Fig. $5 \mathrm{~A}$; maximal contraction $\left[33^{\circ} \mathrm{C}+\right.$ methylene blue: 112 $\pm 18 \%$ versus $\left.33^{\circ} \mathrm{C}: 57 \pm 11 \%\right]$ and $\log \mathrm{ED}_{50}\left[33^{\circ} \mathrm{C}+\right.$ methylene blue: $7.55 \pm 0.10$ versus $\left.33^{\circ} \mathrm{C}: 7.00 \pm 0.14\right]$ : $P<0.001$ versus $33^{\circ} \mathrm{C}$ alone). In addition, the NO-sensitive GC inhibitor ODQ $\left(10^{-5} \mathrm{M}\right)$ increased phenylephrine-induced contraction in endotheliumintact rat aortae at $33^{\circ} \mathrm{C}$ (Fig. 5B: maximal contraction [33 ${ }^{\circ} \mathrm{C}+$ ODQ: $127 \pm 4 \%$ versus $33^{\circ} \mathrm{C}: 60 \pm 8 \%$ ] and $\log \mathrm{ED}_{50}\left[33^{\circ} \mathrm{C}+\mathrm{ODQ}: 7.65 \pm 0.10\right.$ versus $33^{\circ} \mathrm{C}: 6.90$

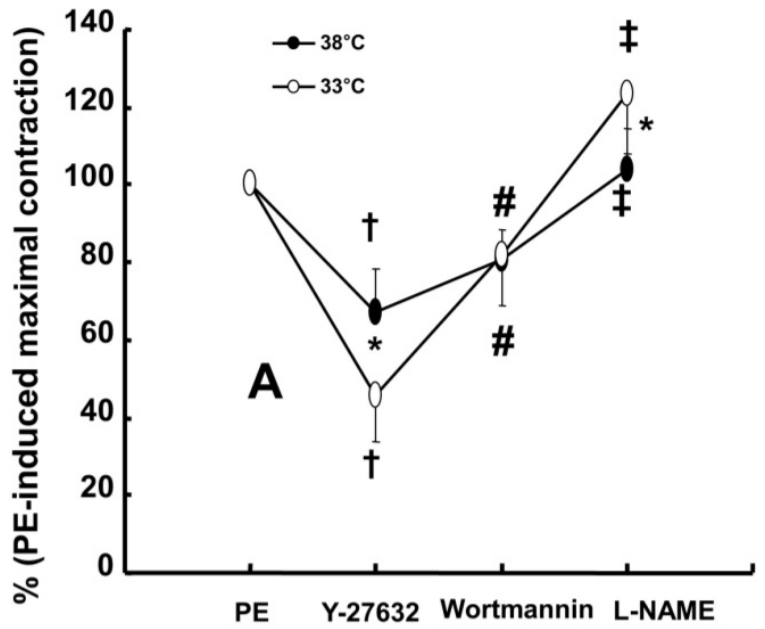

\pm 0.12 ]: $P<0.001$ versus $33^{\circ} \mathrm{C}$ alone).

Both phenylephrine $\left(10^{-8} \mathrm{M}\right)$ and hypothermia $\left(33^{\circ} \mathrm{C}\right)$ induced endothelial nitric oxide synthase (eNOS) Ser ${ }^{1177}$ phosphorylation in HUVECs (Fig. 6; $P$ $<0.001$ versus control). Moreover, compared with $33^{\circ} \mathrm{C}$ or phenylephrine alone, combined treatment with $33^{\circ} \mathrm{C}$ and phenylephrine $\left(10^{-8} \mathrm{M}\right)$ further increased eNOS (Ser ${ }^{1177}$ ) phosphorylation (Fig. 6; $P<$ $0.001)$. Pretreatment with wortmannin $\left(10^{-7} \mathrm{M}\right)$ attenuated the increased phosphorylation of eNOS (Ser ${ }^{1177}$ ) induced by combined treatment with $33^{\circ} \mathrm{C}$ and phenylephrine or phenylephrine alone in HUVECs (Fig. 6; $P<0.001$ ). L-NAME increased phenylephrine-induced eNOS Ser ${ }^{1177}$ phosphorylation (Supplementary Fig. 1).

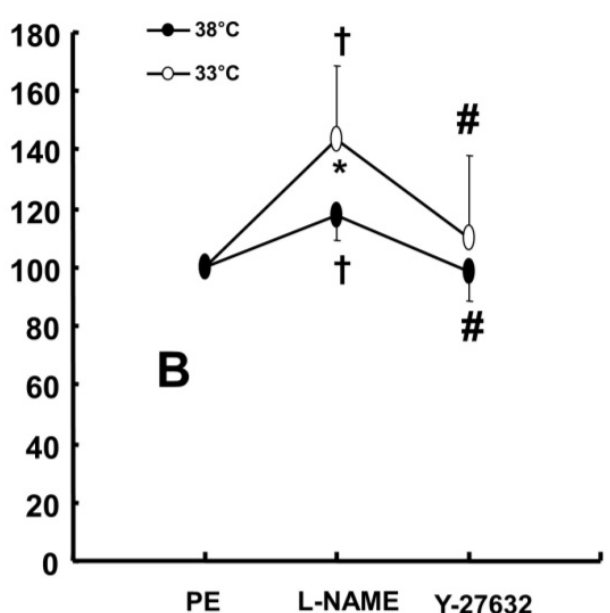

Figure 4. A: Effect of cumulative addition of Y-27632 (10-6 M), wortmannin (10-7 M) and $\mathrm{N}^{\omega}$-nitro-L-arginine-methyl ester (L-NAME, 10-4 M) on maximal contraction induced by phenylephrine $\left(P E, 10^{-5} \mathrm{M}\right)$ in isolated endothelium-intact rat aortae pretreated at $33^{\circ} \mathrm{C}$ or $38^{\circ} \mathrm{C}$. The data $(\mathrm{N}=13)$ are shown as the mean $\pm S D$ and the percentage of maximal contraction induced by $P E\left(10^{-5} \mathrm{M}\right)$. N indicates the number of isolated rat aortae. $* P<0.001$ versus $38^{\circ} \mathrm{C}$. $\nmid P<0.001$ versus $P E$ alone. $\# P<$ 0.001 versus Y-27632. $\ddagger P<0.001$ versus wortmannin. B: Effect of combined L-NAME $\left(10^{-4} \mathrm{M}\right)$ and Y-27632 $(10-6 \mathrm{M})$ on maximal contraction induced by PE (10-5 M) in isolated endothelium-intact rat aortae pretreated at $33^{\circ} \mathrm{C}(\mathrm{N}=17)$ or $38^{\circ} \mathrm{C}(\mathrm{N}=18)$. The data are shown as the mean $\pm S D$ and the percentage of maximal contraction induced by $P E\left(10^{-5} \mathrm{M}\right)$. N indicates the number of isolated rat aortae. $* P<0.001$ versus $38^{\circ} \mathrm{C}$. $+P<0.001$ versus $P E$ alone. $\# P<0.001$ versus $L-N A M E$.
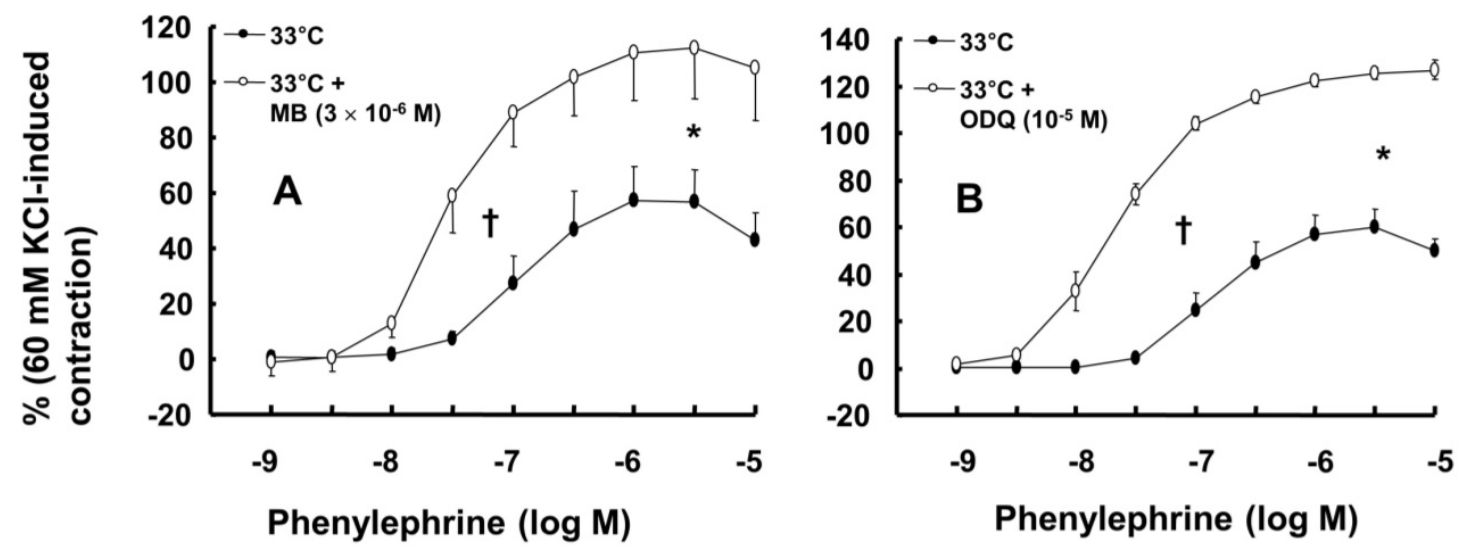

Figure 5. A: Effect of methylene blue (MB, A: $N=7)$ and $1 \mathrm{H}-[1,2,4]$ oxadiazolo[4,3-a]quinoxalin-1-one $(O D Q$, B: $N=8)$ on phenylephrine-induced contraction in isolated endothelium-intact rat aortae pretreated at $33^{\circ} \mathrm{C}$. The data represent the mean $\pm \mathrm{SD}$ and are expressed as a percentage of the maximal contraction induced by isotonic $60 \mathrm{mM} \mathrm{KCl}$. $\mathrm{N}$ indicates the number of isolated rat thoracic aortic rings. Maximal contraction: ${ }^{*} P<0.001$ versus $33^{\circ} \mathrm{C}$ alone. Log $\mathrm{ED}{ }_{50}:+P<0.001$ versus $33^{\circ} \mathrm{C}$ alone. 

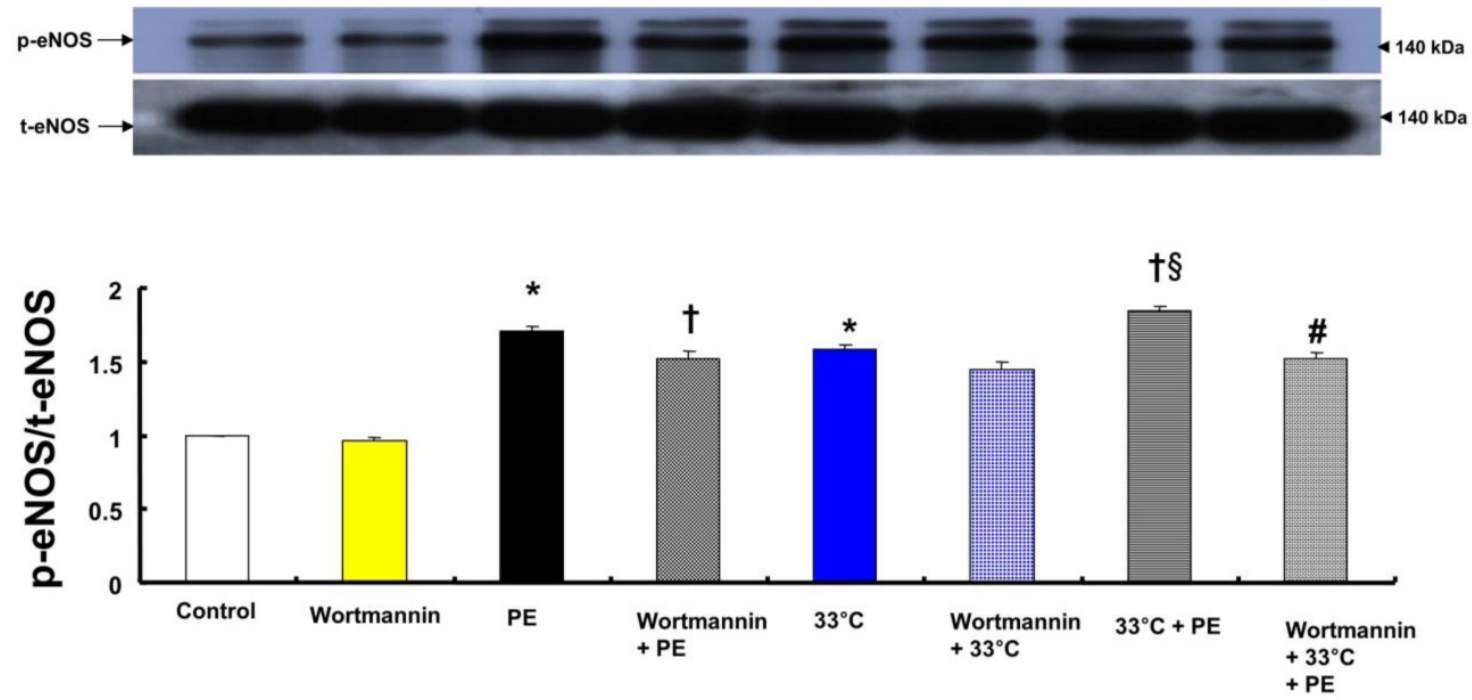

Figure 6. A: Effects of wortmannin and hypothermia, alone and combined, on phenylephrine (PE, 10-8 M)-induced endothelial nitric oxide synthase (eNOS) Ser 1177 phosphorylation in human umbilical vein endothelial cells (HUVECs). HUVECs were treated with wortmannin $\left(10^{-7} \mathrm{M}\right)$ alone at $37^{\circ} \mathrm{C}$ for $1 \mathrm{~h}, \mathrm{PE}\left(10^{-8} \mathrm{M}\right)$ for $1 \mathrm{~min}$, wortmannin $\left(10^{-7} \mathrm{M}\right)$ for $1 \mathrm{~h}$ followed by PE $\left(10^{-8} \mathrm{M}\right)$ for $1 \mathrm{~min}$ at $37^{\circ} \mathrm{C}$, hypothermia $\left(33^{\circ} \mathrm{C}\right)$ alone for $41 \mathrm{~min}$, wortmannin $\left(10^{-7} \mathrm{M}\right)$ at $37^{\circ} \mathrm{C}$ for $1 \mathrm{~h}$ followed by hypothermia $\left(33^{\circ} \mathrm{C}\right)$ for $41 \mathrm{~min}$, hypothermia $\left(33^{\circ} \mathrm{C}\right)$ for $40 \mathrm{~min}$ followed by $\mathrm{PE}\left(10^{-8} \mathrm{M}\right)$ at $33^{\circ} \mathrm{C}$ for $1 \mathrm{~min}$, or wortmannin $\left(10^{-7} \mathrm{M}\right)$ at $37^{\circ} \mathrm{C}$ for $1 \mathrm{~h}$ followed by hypothermia $\left(33^{\circ} \mathrm{C}\right)$ for $40 \mathrm{~min}$ and $\mathrm{PE}\left(10^{-8} \mathrm{M}\right)$ at $33^{\circ} \mathrm{C}$ for $1 \mathrm{~min}$. Data $(\mathrm{N}=3)$ are shown as the mean $\pm S D$. N indicates the number of experiments. $* P<0.001$ versus control. $\dagger P<0.01$ versus $P E$ alone. $\S P<0.001$ versus $33^{\circ} \mathrm{C}$ alone. $\# P<0.001$ versus $33^{\circ} \mathrm{C}+\mathrm{PE}$. p-eNOS: phosphorylated eNOS; t-eNOS: total eNOS.
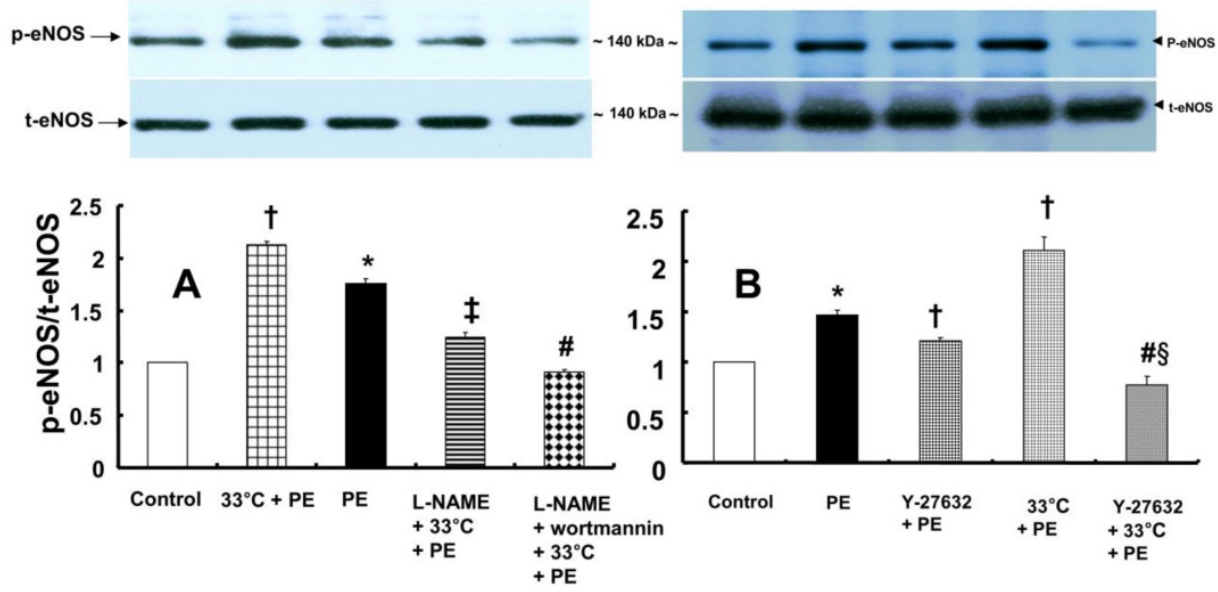

Figure 7. A: Effects of hypothermia, $N^{\omega}$-nitro-L-arginine-methyl ester (L-NAME, 10-4 M) and wortmannin (10-7 M), alone and combined, on phenylephrine (PE, 10-8 M)-induced endothelial nitric oxide synthase (eNOS) Ser 177 phosphorylation in human umbilical vein endothelial cells (HUVECs). HUVECs were treated with PE (10-8 M) for $1 \mathrm{~min}, 33^{\circ} \mathrm{C}$ exposure for $40 \mathrm{~min}$ followed by PE $\left(10^{-8} \mathrm{M}\right)$ for $1 \mathrm{~min}$ at $33^{\circ} \mathrm{C}$, L-NAME $\left(10^{-4} \mathrm{M}\right)$ for $1 \mathrm{~h}$ at $37^{\circ} \mathrm{C}$ followed by $33^{\circ} \mathrm{C}$ exposure for $40 \mathrm{~min}$ and PE $\left(10^{-8} \mathrm{M}\right)$ for $1 \mathrm{~min}$ at $33^{\circ} \mathrm{C}$, or L-NAME $\left(10^{-4} \mathrm{M}\right)$ for $30 \mathrm{~min}$ at $37^{\circ} \mathrm{C}$ followed by $10^{-7} \mathrm{M}$ wortmannin for $30 \mathrm{~min}$ at $37^{\circ} \mathrm{C}, 33^{\circ} \mathrm{C}$ exposure for $40 \mathrm{~min}$ and $10^{-8} \mathrm{M} \mathrm{PE}$ for $1 \mathrm{~min}$ at $33^{\circ} \mathrm{C}$. The data $(\mathrm{N}=3)$ are shown as the mean $\pm S D$. N indicates the number of independent experiments. $* P<0.001$ versus control. $\dagger P<0.001$ versus $P E$ alone. $\ddagger P<0.001$ versus $33^{\circ} \mathrm{C}+\mathrm{PE}$. \#P<0.001 versus L-NAME $+33^{\circ} \mathrm{C}+\mathrm{PE}$. p-eNOS: phosphorylated eNOS; t-eNOS: total eNOS. B: Effects of Y-27632 and hypothermia, alone and combined, on PE (10-8 M)-induced eNOS Serl177 phosphorylation in HUVECs. HUVECs were treated with PE (10-8 M) for 1 min, Y-27632 $\left(10^{-6} \mathrm{M}\right)$ for $1 \mathrm{~h}$ followed by $\mathrm{PE}\left(10^{-8} \mathrm{M}\right)$ for $1 \mathrm{~min}$ at $37^{\circ} \mathrm{C}, 33^{\circ} \mathrm{C}$ exposure for $40 \mathrm{~min}$ followed by $10^{-8} \mathrm{M} \mathrm{PE}$ for $1 \mathrm{~min}$ at $33^{\circ} \mathrm{C}$, or hypothermia $\left(33^{\circ} \mathrm{C}\right)$ for $25 \mathrm{~min}$ followed by $Y-27632(10-6 \mathrm{M})$ at $33^{\circ} \mathrm{C}$ for $15 \mathrm{~min}$ and $\mathrm{PE}\left(10^{-8} \mathrm{M}\right)$ for $1 \mathrm{~min}$. The data $(\mathrm{N}=3)$ are shown as the mean $\pm S D$. N indicates the number of independent experiments. ${ }^{*} P<0.001$ versus control. $\dagger P<0.001$ versus $P E$ alone. $\# P<0.001$ versus $33^{\circ} \mathrm{C}+\mathrm{PE}$. $\S P<0.001$ versus $Y-27632+P E$.

In contrast, pretreatment with L-NAME $\left(10^{-4} \mathrm{M}\right)$ attenuated the increased eNOS (Ser1177) phosphorylation induced by combined treatment with $33^{\circ} \mathrm{C}$ and phenylephrine $\left(10^{-8} \mathrm{M}\right)$ in HUVECs (Fig. 7A; $P<0.001$ ). Compared with L-NAME alone, combined treatment with L-NAME and wortmannin further decreased eNOS (Ser ${ }^{1177}$ ) phosphorylation in aortae that had been previously treated with phenylephrine at $33^{\circ} \mathrm{C}$ (Fig. 7A; $P<0.001$ ). Y-27632 $\left(10^{-6} \mathrm{M}\right)$ attenuated eNOS $\left(\operatorname{Ser}^{1177}\right)$ phosphorylation induced by phenylephrine alone or combined treatment with hypothermia and phenylephrine (Fig. 7B: $P$ < 0.001). However, Y-27632-mediated inhibition of phenylephrine-induced eNOS (Ser $\left.{ }^{1177}\right)$ phosphorylation was more pronounced in mild hypothermia than at $37{ }^{\circ} \mathrm{C}$ (Fig. 7B; $P<0.001$ ). Phenylephrine induced endothelial Rho-kinase (ROCK-2) membrane translocation in HUVECs (Fig. $8 \mathrm{~A} ; \mathrm{P}<0.01)$, and mild hypothermia $\left(33^{\circ} \mathrm{C}\right)$ increased phenylephrine $\left(10^{-8} \mathrm{M}\right)$-induced Rho-kinase (ROCK-2) 

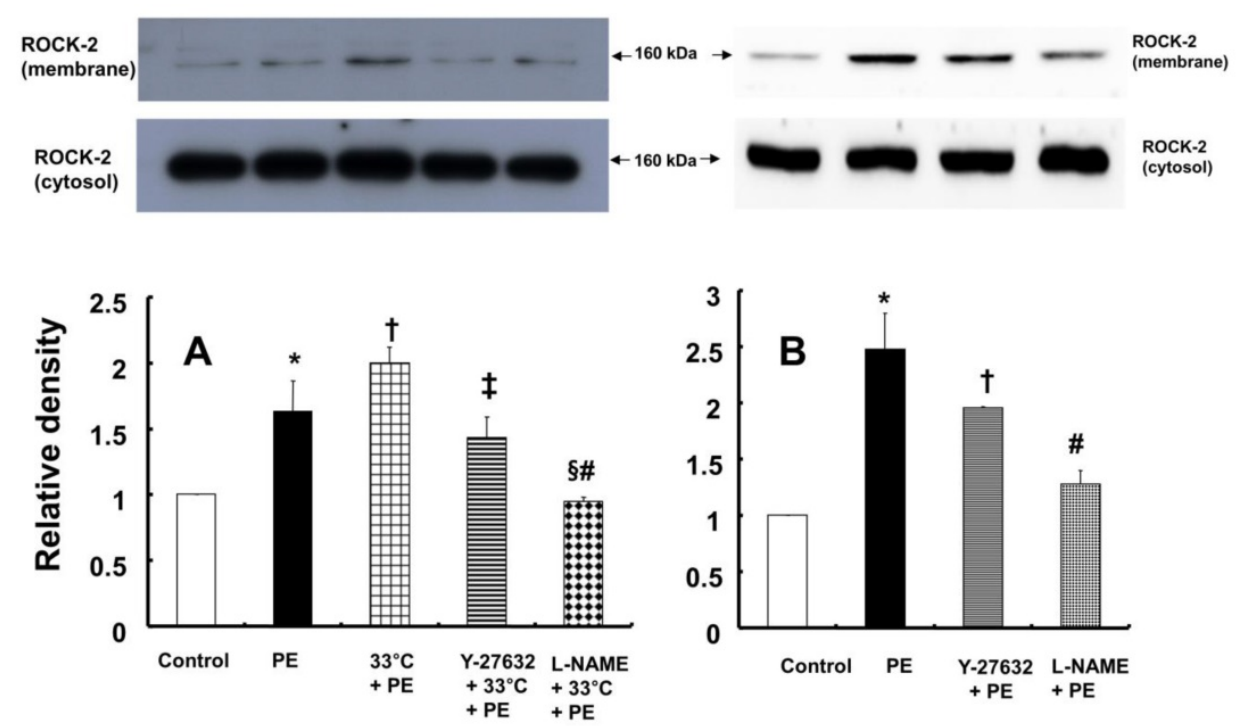

Figure 8. A: Effects of hypothermia, Y-27632 (10-6 M) and $\mathrm{N}^{\omega}$-nitro-L-arginine-methyl ester (L-NAME, 10-4 M), alone and combined, on phenylephrine (PE, 10-8 M)-induced endothelial Rho-kinase (ROCK-2) membrane translocation in human umbilical vein endothelial cells (HUVECs). HUVECs were treated with PE (10-8 M) alone for $5 \mathrm{~min}$, pretreated with $33^{\circ} \mathrm{C}$ exposure for 40 min followed by PE (10-8 M) for 5 min at $33^{\circ} \mathrm{C}$, or pretreated with either $10^{-6} \mathrm{M}$ Y-27632 or $10^{-4} \mathrm{M}$ L-NAME for $1 \mathrm{~h}$ at $37^{\circ} \mathrm{C}$ followed by $33^{\circ} \mathrm{C}$ exposure for $40 \mathrm{~min}$ and subsequent treatment with $10-8 \mathrm{M} \mathrm{PE}$ for $5 \mathrm{~min}$ at $33^{\circ} \mathrm{C}$. The data $(\mathrm{N}=3)$ are shown as the mean $\pm \mathrm{SD}$. $\mathrm{N}$ indicates the number of independent experiments. $* P<0.01$ versus control. $\dagger P<0.05$ versus $P E$ alone. $\ddagger P<0.01$ and $\S P<0.001$ versus $33^{\circ} \mathrm{C}+P E$. $\# P<0.01$ versus $\mathrm{Y}-27632+33^{\circ} \mathrm{C}+\mathrm{PE}$. B: Effects of Y-27632 (10-6 M) and L-NAME $\left(10^{-4} \mathrm{M}\right)$ on PE $\left(10^{-8} \mathrm{M}\right)$-induced endothelial ROCK-2 membrane translocation at $37^{\circ} \mathrm{C}$ in HUVECs. HUVECs were treated with PE (10-8 M) alone for 5 min or pretreated with either 10-6 M Y-27632 or 10-4 M L-NAME for 1 h followed by 10-8 M PE for 5 min. The data $(N=3)$ are shown as the mean $\pm S D$. $N$ indicates the number of independent experiments. $* P<0.001$ versus control. $\dagger P<0.05$ and $\# P<0.001$ versus PE alone.

membrane translocation (Fig. 8A; $P<0.05$ versus phenylephrine alone). Both Y-27632 $\left(10^{-6} \mathrm{M}\right)$ and L-NAME $\left(10^{-4} \mathrm{M}\right)$ attenuated the enhancement of Rho-kinase (ROCK-2) membrane translocation induced by phenylephrine $\left(10^{-8} \mathrm{M}\right)$ and hypothermia (Fig. 8A; $P<0.01$ versus $33^{\circ} \mathrm{C}+$ phenylephrine). Y-27632 and L-NAME also inhibited phenylephrine $\left(10^{-8} \mathrm{M}\right)$-induced ROCK-2 membrane translocation at $37^{\circ} \mathrm{C}$ (Fig. $8 \mathrm{~B} ; P<0.05$ versus phenylephrine).

\section{Discussion}

This study suggests that inhibition of phenylephrine-induced contraction by hypothermia is mediated by PI3K, which seems to be negatively regulated by endothelial Rho-kinase activation in isolated rat aortae (Fig. 9). The major findings of this study were as follows: 1) mild hypothermia attenuated phenylephrine-induced contraction only in endothelium-intact rat aortae; 2 ) pretreatment with wortmannin abolished hypothermia-induced inhibition of phenylephrine-induced contraction; 3) posttreatment with wortmannin abolished the enhancing effect of mild hypothermia on the Y-27632-mediated inhibition of phenylephrine-induced contraction (Fig. $4 \mathrm{~A})$; 4) wortmannin inhibited hypothermia-induced enhancement of eNOS phosphorylation by phenylephrine in HUVECs; and 5) Y-27632 inhibited hypothermia-induced enhancement of endothelial Rho-kinase (ROCK-2) membrane translocation induced by phenylephrine.

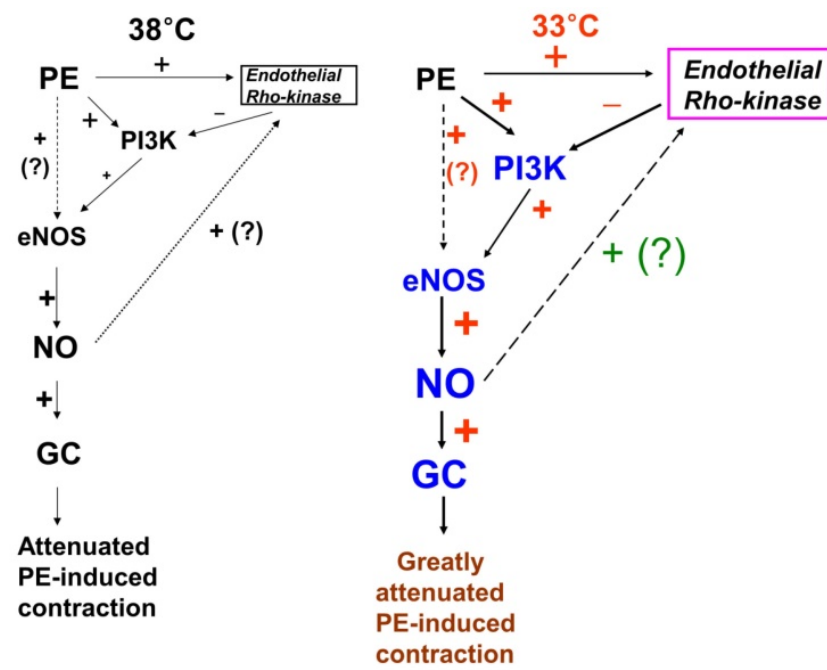

Figure 9. Putative cellular signaling pathways associated with nitric oxide (NO)-mediated inhibition of phenylephrine (PE)-induced contraction in response to mild hypothermia in isolated endothelium-intact rat aortae [6]. +: stimulation. -: inhibition. PI3K: phosphoinositide 3-kinase. eNOS: endothelial nitric oxide synthase. GC: guanylate cyclase. ?: unknown pathway. Line thickness and font size of plus or minus signs represent the magnitude of stimulation or inhibition.

In the current study, the inhibitory effect of mild hypothermia on phenylephrine-induced contraction required an intact endothelium (Fig. $1 \mathrm{~A}$ and $\mathrm{B}$ ). L-NAME increased phenylephrine-induced contraction of endothelium-intact aortae at $33^{\circ} \mathrm{C}$ (Fig. 2B). However, when endothelium-intact aortae were pretreated with L-NAME, there was no significant 
difference in phenylephrine-induced contraction with mild hypothermia $\left(33^{\circ} \mathrm{C}\right.$ ) compared to $38^{\circ} \mathrm{C}$ (Table 2). Similar to previous reports, these results suggest that inhibition of phenylephrine-induced contraction in response to mild hypothermia seems to be mediated by enhanced NO production $[3,5]$. Consistent with the results from the current tension study, we found that compared with hypothermia or phenylephrine alone, combined treatment with hypothermia $\left(33^{\circ} \mathrm{C}\right)$ and phenylephrine enhanced eNOS phosphorylation (Fig. 6) but that L-NAME inhibited hypothermia $\left(33^{\circ} \mathrm{C}\right)$-induced augmentation of phenylephrineinduced eNOS phosphorylation (Fig. 7A). As hypothermia causes decreased phenylephrineinduced contraction due to increase NO availability, this L-MANE-induced inhibition of eNOS phosphorylation resulting from combined treatment with phenylephrine and hypothermia seems to be associated with a L-NAME-induced decrease in NO production $[4,5,22]$. However, the L-NAME-induced increase in eNOS phosphorylation caused by phenylephrine alone at $37^{\circ} \mathrm{C}$ may be associated with compensatory eNOS activation due to competitive inhibition of L-NAME against L-arginine as a substrate of NO (supplementary Fig. 1). Furthermore, the GC inhibitor methylene blue and the NO-sensitive GC inhibitor ODQ enhanced phenylephrine-induced contraction in endothelium-intact rat aortae pretreated at $33^{\circ} \mathrm{C}$ (Fig. 5A and B). Taken together, these results suggest that hypothermia-induced activation of the NO-GC pathway contributes to endothelium-dependent attenuation of phenylephrine-induced contraction.

The PI3K/Akt pathway is involved in endothelial NO production $[6,7,22]$. Similar to previous studies, the current study found that the PI3K inhibitor wortmannin $\left(10^{-7} \mathrm{M}\right)$ abolished mild hypothermia-induced NO-mediated inhibition of phenylephrine-induced maximal contraction (Fig. 2A) $[6,7,23]$. Furthermore, wortmannin caused the concentration-response curve for phenylephrineinduced contraction to shift to the left at $38^{\circ} \mathrm{C}$ (Fig. $2 \mathrm{~A})$, whereas it greatly increased phenylephrineinduced maximal contraction at $33^{\circ} \mathrm{C}$ (Fig. 3A). This wortmannin-induced increase in the enhancement of phenylephrine-induced maximal contraction at $33^{\circ} \mathrm{C}$ seems to be associated with the inhibition of PI3K-induced NO production. However, wortmannin had no effect on L-NAME $\left(10^{-4} \mathrm{M}\right)$-induced enhancement of phenylephrine $\left(10^{-5} \mathrm{M}\right)$-induced maximal contraction at $33^{\circ} \mathrm{C}$ (Fig. 3B). In agreement with the results from the tension study, wortmannin inhibited the enhancement of eNOS phosphorylation induced by combined hypothermia and phenylephrine treatment or phenylephrine alone (Fig.
6). Taken together, these results suggest that hypothermia-induced PI3K activity contributes to enhanced NO production, which leads to decreased phenylephrine-induced contraction of endotheliumintact aortae. However, pretreatment with L-NAME followed by treatment with wortmannin in HUVECs attenuated the hypothermia-induced enhancement of phenylephrine-induced eNOS phosphorylation compared with L-NAME alone (Fig. 7A). This inconsistency between the tension study and the Western blot analysis may be due to differences in species (human versus rat) and vessels (aorta versus umbilical artery). Rho-kinase in the vascular smooth muscle induces vasoconstriction by inhibiting MLCP, which leads to increased phosphorylation of the $20-\mathrm{kDa}$ regulatory light chain of myosin [24]. Additionally, endothelial Rho-kinase activation decreases endothelial NO release via inhibition of PI3K/Akt [7,11]. Thus, hypothermia-induced Rhokinase activation produces vasoconstriction via both inhibition of MLCP and attenuation of NO release $[7,11,13]$. The Rho-kinase inhibitor Y-27632 potently decreased phenylephrine-induced maximal contraction under mild hypothermia compared with $38^{\circ} \mathrm{C}$ (Fig. 4A). Cotreatment with Y-27932 and wortmannin has been reported to partially reverse Y-27632induced inhibition of phenylephrine-induced contraction in endothelium-intact rat aortae but not in endothelium-denuded rat aortae or endotheliumintact aortae pretreated with L-NAME [6]. This suggests that Rho-kinase inhibitor-mediated inhibition of phenylephrine-induced contraction is associated with uninhibited PI3K-induced endothelial NO production [6]. Thus, considering previous reports, the increased Y-27632-induced inhibition of phenylephrine-induced maximal contraction observed at $33^{\circ} \mathrm{C}$ (Fig. 4A) may be due mainly to increase NO production via increased activation of PI3K [6]. As in a previous report, subsequent treatment with wortmannin abolished the enhancing effect of Y-27632 on the inhibition of maximal phenylephrineinduced contraction observed at $33^{\circ} \mathrm{C}$ (Fig. 4A) [6]. Taken together, these results suggest that, as hypothermia enhanced endothelial Rho-kinase membrane translocation induced by phenylephrine (Fig. $8 \mathrm{~A})$, mild hypothermia $\left(33^{\circ} \mathrm{C}\right)$-induced endothelial Rho-kinase membrane translocation contributes to enhanced contraction via PI3K inhibition-mediated decreased NO production $[6,7,11,13]$. This response may be associated with a compensatory mechanism to counterbalance hypothermia-induced endothelial NO production. In endothelium-intact aortae pretreated with Y-27632 and wortmannin, the subsequent addition of L-NAME enhanced phenylephrine-induced contrac- 
tion under conditions of mild hypothermia compared with $38^{\circ} \mathrm{C}$. This result suggests that other NO production pathways that are not mediated by PI3K may contribute to the decrease in phenylephrineinduced maximal contraction in mild hypothermia. L-NAME enhanced phenylephrine-induced maximal contraction in mild hypothermia compared with $38^{\circ} \mathrm{C}$, but after addition of the Rho-kinase inhibitor Y-27632, contraction decreased to similar levels at both $33^{\circ} \mathrm{C}$ and $38^{\circ} \mathrm{C}$ (Fig. 4B). This lack of significant difference in phenylephrine-induced maximal contraction between 38 and $33^{\circ} \mathrm{C}$ with the addition of Y-27632 following pretreatment with L-NAME (Fig. 4B) may be due to increased inhibition of mild hypothermiainduced, Rho-kinase-mediated enhancement of vascular smooth muscle cell contraction caused by the relative activation of MLCP in the vascular smooth muscle [13,24]. Consistent with the tension study, Y-27632 attenuated the hypothermia-induced enhancement of endothelial Rho-kinase membrane translocation induced by phenylephrine (Fig. 8A). However, pretreatment with L-NAME caused greater inhibition of hypothermia- and phenylephrineinduced enhancement of endothelial Rho-kinase membrane translocation compared with pretreatment with Y-27632 (Fig. 8A). Reciprocally, Y-27632mediated inhibition of phenylephrine-induced eNOS phosphorylation was enhanced in mild hypothermia conditions compared with $37^{\circ} \mathrm{C}$ (Fig. 7B). These results suggest that the putative underlying mechanism for L-NAME's inhibition of endothelial Rho-kinase membrane translocation increased by phenylephrine and hypothermia (Fig 8A) and Y-27632's inhibition of phenylephrine- and hypothermia-induced eNOS phosphorylation (Fig. 7B) is as follows [25]. Given that mild hypothermia (33 $\left.{ }^{\circ} \mathrm{C}\right)$ enhanced phenylephrine-induced eNOS phosphorylation and ROCK-2 membrane transloncation (Fig 6 and 8A) and that the ability of mild hypothermia to attenuate phenylephrine-induced contraction involves PI3K-mediated endothelial NO release (Fig. 3A and B) and Rho-kinase activation (Fig. $4 \mathrm{~A})$, enhanced NO release in hypothermia may activate endothelial Rho-kinase to counterbalance excessive NO-mediated attenuation of phenylephrine-induced contraction (Fig. 9) $[7,13]$. Thus, pretreatment with L-NAME at $33^{\circ} \mathrm{C}$ may contribute to decreased Rho-kinase membrane translocation through the inhibition of NO production induced by mild hypothermia. On the other hand, activation of the NO-cGMP pathway inhibits the RhoA/ROCK pathway [25]. The relationship between the Rho-kinase pathway and the NO-cGMP pathway in the mildly hypothermic endothelium remains to be characterized in detail.
The clinical relevance of this study is as follows. When hypotension is encountered during therapeutic mild hypothermia, drugs that inhibit the NO-GCcGMP pathway, including methylene blue, may be effective in restoring normal blood pressure. In addition, as statins, which lower cholesterol levels, attenuate the activity of Rho-kinase, patients concurrently taking statins during therapeutic mild hypothermia may face more severe hypotension than patients not taking statins [11]. The limitations of this study are as follows. First, small resistance arterioles are the main determinants of vascular resistance and contribute to blood pressure, but the aorta, a large conduit artery, was used in the current study [26]. Second, rat aortae were used for the tension study, whereas HUVECs were used to detect eNOS phosphorylation and Rho-kinase membrane transloncation. Third, this in vitro study did not consider the heart or the nervous system, which are important for regulating hemodynamics in vivo. Fourth, based on the previous reports, $38^{\circ} \mathrm{C}$ was used for tension experiment to compensate for heat loss during circulation of heated water in the organ bath $[3,5]$. However, $37^{\circ} \mathrm{C}$ was used for experiment using HUVECs.

In conclusion, mild hypothermia attenuated phenylephrine-induced contraction in isolated rat aortae via the NO-GC pathway, partially through regulation by $\mathrm{PI} 3 \mathrm{~K}$, and this phenomenon seems to be inhibited by endothelial Rho-kinase (Fig. 9).

\section{Abbreviations}

NO: nitric oxide; cGMP: cyclic guanosine monophosphate; PI3K: phosphoinositide 3-kinase; MLCP: myosin light chain phosphatase; HUVEC: human umbilical vein endothelial cell; eNOS: endothelial nitric oxide synthase; GC: guanylate cyclase; L-NAME: ${ }^{\omega}{ }^{-}$-nitro-L-arginine methyl ester; ODQ: 1H-[1,2,4]oxadiazolo[4,3-a]quinoxalin-1-one.

\section{Supplementary Material}

Supplementary figure S1.

http://www.medsci.org/v17p0021s1.pdf

\section{Acknowledgements}

This research was supported by Basic Science Research Program through the National Research Foundation of Korea (NRF) funded by the Ministry of Education (NRF-2018R1D1A1B07043914). This research was supported by Basic Science Research Program through the National Research Foundation of Korea (NRF) funded by the Ministry of Education (NRF-2016R1D1A1B03930451). 


\section{Competing Interests}

The authors have declared that no competing interest exists.

\section{References}

1. Sandestig A, Romner B, Grände PO. Therapeutic hypothermia in children and adults with severe traumatic brain injury. Ther Hypothermia Temp Manag. 2014; 4: 10-20.

2. Dash HH, Chavali S. Management of traumatic brain injury patients. Korean J Anesthesiol. 2018; 71: 12-21.

3. Lagneau F, Kirstetter P, Bernard C, Marty J. Effect of mild hypothermia on the vascular actions of phenylephrine in rat aortic rings. Br J Anaesth. 1999; 82: 938-940.

4. Karaki H, Nagase H. Low temperature augments the endothelium-dependent relaxation in isolated rat aorta. Eur J Pharmacol 1987; 142: 129-132.

5. Chung JY, Kim JE, Yoon HJ, Song SY, Kim SO, Roh WS. Moderate hypothermia attenuates $a(1)$-adrenoceptor-mediated contraction in isolated rat aorta: the role of the endothelium. Cryobiology 2012; 65: 33-40.

6. Budzyn K, Marley PD, Sobey CG. Opposing roles of endothelial and smooth muscle phosphatidylinositol 3-kinase in vasoconstriction: effects of rho-kinase and hypertension. J Pharmacol Exp Ther. 2005; 313: 1248-1253.

7. Yao L, Romero MJ, Toque HA, Yang G, Caldwell RB, Caldwell RW. The role of RhoA/Rho kinase pathway in endothelial dysfunction. J Cardiovasc Dis Res. 2010; 1: 165-170.

8. Teixeira CE, Jin L. Ying Z, Palmer T, Priviero FB, Webb RC. Expression and functional role of the RhoA/Rho-kinase pathway in rat coeliac artery. Clin Exp Pharmacol Physiol 2005; 32: 817-824.

9. Chitaley K, Webb RC. Nitric oxide induces dilation of rat aorta via inhibition of rho-kinase signaling. Hypertension 2002; 39: 438-442

10. Mills TM, Lewis RW, Wingard CJ, Linder AE, Jin L, Webb RC. Vasoconstriction, RhoA/Rho-kinase and the erectile response. Int J Impot Res. 2003; Suppl 5: S20-S24.

11. Le Manach, $Y$ Coriat $P$, Collard CD, Riedel B. Statin therapy within the perioperative period. Anesthesiology 2008; 108: 1141-1146.

12. Naraoka M, Munakata A, Matsuda N, Shimamura N, Ohkuma H. Suppression of the Rho/Rho-kinase pathway and prevention of cerebral vasospasm by combination treatment with statin and fasudil after subarachnoid hemorrhage in rabbit. Transl Stroke Res.2013; 4: 368-374.

13. Thompson-Torgerson CS, Holowatz LA, Kenney WL. Altered mechanisms of thermoregulatory vasoconstriction in aged human skin. Exerc Sport Sci Re. 2008; 36: 122-127.

14. Lee SH, Kwon SC, Ok SH, Hong JM, Kim JY, Ahn SH, Bae SI, Shin Y, Sohn JT. Levobupivacaine-induced vasoconstriction involves caldesmon phosphorylation mediated by tyrosine kinase-induced ERK phosphorylation. Eur J Pharmacol. 2019; 842: 167-176.

15. Lee SH, Kang D, Ok SH, Kwon SC, Kim HJ, Kim EJ, Hong JM, Kim JY, Bae SI, An S, Sohn JT. Linoleic acid attenuates the toxic dose of bupivacaine-mediated reduction of vasodilation evoked by the activation of adenosine triphosphate-sensitive potassium channels. Int J Mol Sci. 2018, pii:E1876. doi: $10.3390 /$ ijms 19071876

16. Oloyo AK, Elias SO, Sofola OA. Differential responses to endothelial-dependent relaxation of the thoracic and abdominal aorta from male Sprague-Dawley rats. Niger J Physiol Sci. 2012; 27: 117-122

17. Li LR, You C, Chaudhary B. Intraoperative mild hypothermia for postoperative neurological deficits in people with intracranial aneurysm. Cochrane Database Syst Rev. 2016, CD008445. doi: 10.1002/14651858

18. Shim HS, Ok SH, Lee SH, Kwon SC, Sohn JT. Protein kinases participate in the contraction in response to levobupivacaine in the rat aorta. Eur J Pharmacol. 2012; 677: 131-137.

19. Ok SH, Han JY, Sung HJ, Yang SM, Park J, Kwon SC, Choi MJ, Sohn JT. Ropivacaine-induced contraction is attenuated by both endothelial nitric oxide and voltage-dependent potassium channels in isolated rat aortae. Biomed Res Int. 2013, 2013, 565271, doi: 10.1155/2013/565271.

20. Byon HJ, Ok SH, Lee SH, Kang S, Cho Y, Han JY, Sohn JT. Dexmedetomidine inhibits phenylephrine-induced contractions via alpha-1 adrenoceptor blockade and Nitric Oxide Release in Isolated Rat Aortae. Int J Med Sci. 2017; 14: 143-149.

21. Subbarao RB, Ok SH, Lee SH, Kang D, Kim EJ, Kim JY, Sohn JT. Lipid emulsion inhibits the late apoptosis/cardiotoxicity induced by doxorubicin in rat cardiomyoblasts. Cells 2018, pii: E144. doi: 10.3390/cells7100144.

22. Nurullahoglu-Atalik KE, Cenker A. Moderate hypothermia attenuates $a(1)$-adrenoceptor-mediated contraction in human varicose spermatic vein: The role of nitric oxide(Short communication). Physiol Int. 2016; 103: 481-486.

23. Dimmeler S, Fleming I; Fisslthaler B; Hermann C; Busse R; Zeiher AM. Activation of nitric oxide synthase in endothelial cells by Akt-dependent phosphorylation. Nature 1999; 399: 601-605.

24. Akata T. General anesthetics and vascular smooth muscle: direct actions of general anesthetics on cellular mechanisms regulating vascular tone. Anesthesiology 2007; 106: 365-391.
25. Luo W, Liu CT, Yang QH, Yu Q, Wang T. New angle of view on the role of rho/rho kinase pathway in human diseases. Iran J Allergy Asthma Immunol. 2014; 13: 378-395.

26. Mayet J, Hughes A. Cardiac and vascular pathophysiology in hypertension. Heart 2003; 89: 1104-1109. 